\title{
SYSTEMIC OXIDATIVE STRESS AS A SURROGATE OF CORONARY ATHEROSCLEROTIC PLAQUE INSTABILITY AND RUPTURE PREDICTOR
}

\author{
Z. Lominadze', *K. Chelidze², L. Chelidze², E. Lominadze ${ }^{2}$ \\ 1 - LTD CLINIC-LI, KUTAISI, GEORGIA \\ 2 - TBILISI STATE MEDICAL UNIVERSITY, TBILISI, GEORGIA
}

\begin{abstract}
Background. Oxidative stress is crucial in developing broad spectrum of diseases, including atherosclerosis and related life-threatening conditions, such as acute coronary syndrome (ACS) mainly caused by atherosclerotic plaque vulnerability.

Objective. To clarify the relation between oxidative stress and plaque instability we decided to compare oxidative profiles of patients with acute coronary syndrome (ACS) and with chronic coronary syndrome (CCS), evaluated at admission to the coronary care unit (CCU) of LTD Clinic-LJ (Kutaisi, Georgia) in April 2018 -June 2019, who underwent successful primary percutaneous coronary intervention (PCI).

Methods. 191 patients were enrolled (100 patients with ACS in Group 1 and 91 patients with CCS in Group 2) into the study. Using the CR3000 FORM PLUS (Callegari Srl, Catellani Group, Italy) - Callegari Point of Care instrument we evaluated free oxygen radical test (FORT), free oxygen radicals defense (FORD), calculated REDOX Index and the overall Profile of oxidative stress.

Results. The mean/median concentration of Free Oxygen Radicals was significantly higher in the patients

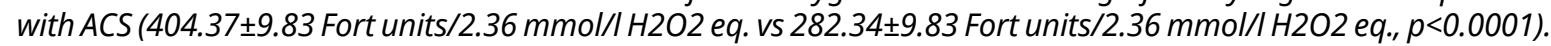
Significant correlation was found between advanced oxidative stress and acute coronary syndrome (OR 14.42 95\% CI (7.08-29.4), RR 3.26 95\% CI (2.31-4.60) with high diagnostic characteristics (sensitivity of 82\% and specificity of 92.3\%; positive predictive value of $92 \%$ and positive likelihood ratio of 11).

Conclusion. Oxidative stress is crucial in life-threatening acute coronary events. Measurement of overall oxidative stress profile, as a surrogate of plaque instability and rupture predictor, could help the clinicians in risk stratification and prevention of acute coronary syndrome (ACS).

KEY WORDS: acute coronary syndrome (ACS); chronic coronary syndrome (CCS); oxidative stress; free oxygen radical test (FORT); free oxygen radicals defense test (FORD); REDOX index; oxidative stress profile; vulnerable plaque; plaque rupture.
\end{abstract}

\section{Introduction}

Coronary heart disease (CHD) has remained the leading cause of death globally in the last two decades. According to the World Health Organization Global Health Observatory (GHO) data IHD is the world's biggest killer, accounting for 9.33 million deaths in 2016 [1].

Acute coronary syndrome (ACS) is a clinical manifestation of CHD with variable consequences range from unstable angina (UA) to non-ST elevation myocardial infarction (NSTEMI), STelevation myocardial infarction (STEMI), and sudden cardiac death. Acute coronary syndrome (ACS) mainly as a result of plaque disruption in coronary arteries is responsible for one-third of total deaths in people older than 35 [2].

The main therapeutic approach to ACS is focused on interventional techniques designed to restore blood flow in hemodynamically

*Corresponding author: Kakhaber Chelidze, The First University Clinic of Tbilisi State Medical University (TSMU), 4 Gudamakari str. Tbilisi. 0141.

E-mail: k.chelidze@tsmu.edu compromised coronary arteries. However, this reactive strategy has a weak preventive effect on future coronary events. Although pharmacotherapy with antiplatelet agents and statins does not have a dramatic risk-lowering effect as well $[3,4]$.

In the last 10 years, a major improvement has been made in an effort to understand one of the main mechanisms of ACS: the concept of vulnerable plaque as a cause of major ischemic events [5].

The term "vulnerable plaque" was originally used to define a plaque prone to rupture. However, apart from rupture the term "vulnerability" includes other types of lesion, such as plaque erosion, and plaque calcification [6].

The vulnerable plaque is made of a large lipid core (foam cells, apoptotic/necrotic cells, and debris) [7] which is separated from the lumen by a fibrous cap (mainly comprising collagen, proteoglycans, and smooth muscle cells) $[8,9]$. Weakening of the fibrous cup under different stressors and a lack of healing results 
in plaque fissuring, thrombus formation and, therefore, in acute coronary syndrome $[10,11]$.

Many clinical studies support a crucial role for oxidative stress in cardiovascular diseases $[12,13]$. Oxidative stress (imbalance between enhanced production of reactive oxygen species (ROS) and enzymatic/nonenzymatic antioxidative potential accountable for oxidative modification of low-density lipoprotein cholesterol (LDLC) and cell damage (including endothelial cells of vessels) initiate fatty streak formation, lesion progression, and plaque rupture $[14,15]$.

It is very important to identify reliable surrogates of plaque instability and predict the highest risk of rupture. The present study intended to determine the oxidative status in patients with acute coronary syndrome (ACS) and to compare with oxidative/antioxidative parameters in patients with stable ischemic heart disease (SIHD). These findings could help assess the risk of stratification and prevent acute coronary syndrome (ACS).

\section{Materials and methods}

Study patients

The study sample consisted of 191 patients who were divided into two groups: Group 1 100 patients with acute coronary syndrome (ASC) and Group 2 - 91 patients with chronic coronary syndrome (CCS) admitted to the coronary care unit (CCU) of LTD Clinic-LJ (Kutaisi, Georgia) in April 2018 - June 2019, who under went successful primary percutaneous coronary intervention (PCI). In the patients with chronic coronary syndrome (CCS) invasive coronary angiography with revascularization was performed in case of high clinical likelihood of obstructive coronary artery disease (OCAD) and severe symptoms refractory to optimal medical treatment, or typical angina at a low level of exercise and clinical prediction of high-risk of events, or left ventricular dysfunction suggestive of CAD.

Patients with a history of coronary revascularization, or with hemodynamically compromised severe myocardial infarction; those recovering cardiopulmonary arrest, decompensated heart failure; and those with valvular heart disease, cardiomyopathy, severe supraventricular/ventricular arrhythmias (including atrial fibrillation) and conductivity disturbances, end-stage renal disease (ESRD), chronic inflammatory conditions, active cancer, type 1 diabetes mellitus (DM) or decompensated type 2 diabetes mellitus (DM); pregnancy; those on hormone replacement therapy (HRT) or oral contraceptive assumption were excluded from the study. No corrections or changes had been made in the ongoing pharmacotherapy of the patients. All essential laboratory tests and FORT/FORD assays were performed during the first hour of admission.

The study was approved by the Ethics Committee (EC) of Tbilisi State Medical University (TSMU) and local EC of LTD Clinic-LJ and a written informed consent was provided by each study participants.

Assay of oxidative stress

The enrolled patients' oxidative status was assessed by measuring ROS damage index (FORT test) and antioxidant capacity (FORD test), and REDOX index calculation using the CR3000 FORM PLUS (CallegariSrl, Catellani Group, Italy) - Callegari Point of Care instrument with following technical characteristics:

Parameters measured and specificity: (i) free oxygen radical test (FORT): overall organic radicals, e.g. Hydroperoxides, (ROOHs)/reactive oxygen species (ROS); (ii) free oxygen radicals defense (FORD): plasmatic antioxidant compounds including vitamin C; proteins (e.g. albumin and ceruloplasmin); bilirubin; thiol groups (e.g. glutathione); polyphenolic compounds (e.g. flavonoids and tannins); (iii) Oxidativereductive balance (REDOX index): overall score of the oxidation-reduction state. The index was expressed as a number (from 0 to 100) identifying 5 specific profiles (A-E).

Assay principle: (i) free oxygen radical test (FORT): colorimetric method based on the Fenton reaction; (ii) free oxygen radicals defense (FORD): colorimetric method based on the quenching of the color.

Reference range: (i) free oxygen radical test (FORT): Up to 310 Fort units $/ 2.36 \mathrm{mmol} / \mathrm{I} \mathrm{H}_{2} \mathrm{O}_{2}$ eq; (ii) free oxygen radicals defense (FORD): $1.07-1.53 \mathrm{mmol} / \mathrm{l}$ trolox eq.;

Sample type: whole blood;

Technique: Point of care analysis via ready to use, wet, disposable reagents;

Wavelength: $505 \mathrm{~nm}$.

The five profiles of oxidative stress were determined by basal FORT and FORD values and REDOX index calculation: (i) Profile A (Ideal/ normal values): redox index: 0-25; FORT $<300$ units $/ 2.36 \mathrm{mmol} / \mathrm{I} \mathrm{H} 2 \mathrm{O} 2$ eq.; FORD $\geq 1.08 \mathrm{mmol} / \mathrm{I}$ trolox eq; (ii) Profile $\mathrm{B}$ (latent oxidative stress): redox index: 25-50; FORT $<300$ units/2.36 $\mathrm{mmol} / \mathrm{l} \mathrm{H} 2 \mathrm{O} 2 \mathrm{eq} ;$ FORD $\leq 1.07 \mathrm{mmol} / \mathrm{I}$ trolox eq.; (iii) Profile $\mathrm{C}$ (compensated oxidative stress): redox index: 50-58.3; $300<$ FORT <330 units/2.36 
$\mathrm{mmol} / \mathrm{l} \mathrm{H} 2 \mathrm{O} 2$ eq; FORD $\geq 1.08 \mathrm{mmol} / \mathrm{l}$ trolox eq.; (iv) Profile $D$ (at risk of oxidative stress): redox index: 58.3-66.6; 300< FORT <330 units/2.36 $\mathrm{mmol} / \mathrm{l} \mathrm{H} 2 \mathrm{O} 2$ eq; FORD $\leq 1.07 \mathrm{mmol} / \mathrm{I}$ trolox eq.; (v) Profile $\mathrm{E}$ (oxidative stress in progress): redox index: 66.6-100; FORT $\geq 331$ units $/ 2.36 \mathrm{mmol} / \mathrm{l}$ $\mathrm{H} 2 \mathrm{O} 2$ eq; $0.25<\mathrm{FORD}<3.00 \mathrm{mmol} / \mathrm{l}$ trolox eq.

Statistical analysis

The data were analyzed using IBM SPSS Statistics version 26.0 (IBM Corp., Armonk, NY, USA). To identify oxidative status differences between two groups with abnormal distribution nonparametric tests were used: (i) MannWhitney $U$ test for 2 samples; (ii) Median Test for $\mathrm{K}$ samples to compare medians across the groups, and (iii) Moses extreme reaction for 2 samples to compare ranges across the groups. Odds ratio (OR) and relative risk (RR) assessment was used to quantify the strength of the association between oxidative stress and acute coronary syndrome (ACS). For assessment of sensitivity/specificity, positive predictive value (PPV), negative predictive value (NPV), likelihood ratio, Youden's J statistic, and prevalence crosstabulation analysis were used. The $95 \%$ confidence interval (CI) was used to estimate the precision of the OR. The $p$ value of 0.05 was considered significant.

\section{Results}

Study population characteristics

Clinical characteristics of the overall study population are shown in Table 1.

There was no statistically significant difference between the study population characteristics, such as age, male gender, BMI, hyper- tension, dyslipidemia, ongoing smoking, type 2 DM, and medications, such as beta-blockers, calcium channel blockers, ACEIs or ARBs, and statins. Nitrates consumption was much higher in the patients with chronic coronary syndrome $(p<0.0001)$.

Admission oxidative stress parameters

Fig. 1 depicts the level of baseline oxidative stress parameters evaluated in whole blood of Group 1 of the patients with acute coronary syndrome (ACS) and Group 2 of the patients with chronic coronary syndrome (CCS). The concentration of free oxygen radicals (FORT, Fort units/2.36 mmol/l $\mathrm{H}_{2} \mathrm{O}_{2}$ eq) evaluated in two groups was as follows: in the patients with ACS, 404.37 \pm 9.83 Fort units $/ 2.36 \mathrm{mmol} / \mathrm{l} \mathrm{H}_{2} \mathrm{O}_{2}$ eq, and in the patients with CCS, 282.34 \pm 9.83 Fort units $/ 2.36 \mathrm{mmol} / \mathrm{I}_{2} \mathrm{O}_{2}$ eq $(p<0.0001)$. Free oxygen radicals defense capacity evaluated by the FORD test in the Group 1 and Group 2 were $1.37 \pm 0.035 \mathrm{mmol} / \mathrm{l}$ Trolox eq. and $1.5 \pm 0.045$ $\mathrm{mmol} / \mathrm{I}$ Trolox eq., respectively $(p=0.03)$. The distribution analysis of the calculated REDOX index in the patients with ACS was $69.2 \pm 1.47$, and in the patients with CCS was $1.5 \pm 0.45$ $(p<0.0001)$. A nominal equivalent of stress profile in both groups distributed as follows: $4.56 \pm 0.1$ and $1.92 \pm 0.13$, respectively in the Group 1 and Group $2(p<0.0001)$.

There are reported results of nonparametric analysis of ROS and antioxidative potential across the groups of patients with ACS and CCS (Fig. 2). Th difference between all oxidative parameters was statistically significant $(p<0.0001)$, except free oxygen radicals defense FORD test $(p=0.1)$.

Table 1. Characteristics of study population

\begin{tabular}{|l|c|c|c|}
\hline & $\begin{array}{c}\text { Group 1 } \\
\text { (Patients with ACS) } \\
\mathbf{n = 1 0 0}\end{array}$ & $\begin{array}{c}\text { Group 2 } \\
\text { (Patients with CCS) } \\
\mathbf{n = 9 1}\end{array}$ & P value \\
\hline Age (years) & $51.8 \pm 0.78$ & $49.1 \pm 1.02$ & 0.236 \\
\hline Male gender, n (\%) & $74(74)$ & $52(57)$ & 0.874 \\
\hline BMI & $27.76 \pm 0.35$ & $27.81 \pm 0.36$ & 0.924 \\
\hline Hypertension, n (\%) & $51(51)$ & $41(45)$ & 0.413 \\
\hline Dyslipidemia, $\mathrm{n}(\%)$ & $62(62)$ & $56(61.5)$ & 0.948 \\
\hline Smoking, $\mathrm{n}(\%)$ & $52(52)$ & $45(49.5)$ & 0.726 \\
\hline Type 2 DM, n (\%) & $44(44)$ & $38(41.8)$ & 0.755 \\
\hline BB, $\mathrm{n}(\%)$ & $31(31)$ & $27(29.7)$ & 0.842 \\
\hline CCB, $\mathrm{n}(\%)$ & $36(36)$ & $28(30.8)$ & 0.446 \\
\hline ACEIs/ARBs, $\mathrm{n}(\%)$ & $42(42)$ & $38(41.8)$ & 0.973 \\
\hline Statins, $\mathrm{n}(\%)$ & $42(42)$ & $45(49.5)$ & 0.238 \\
\hline Nitrates, $\mathrm{n}(\%)$ & $22(22)$ & $42(46.2)$ & $<0.0001$ * \\
\hline
\end{tabular}

Notes. * Statistically significant difference; BMI body mass index, BB beta-blockers, CCB calcium channel blockers, ACSEIs angiotensin converting enzyme inhibitors, ARBs angiotensin receptor blockers. 

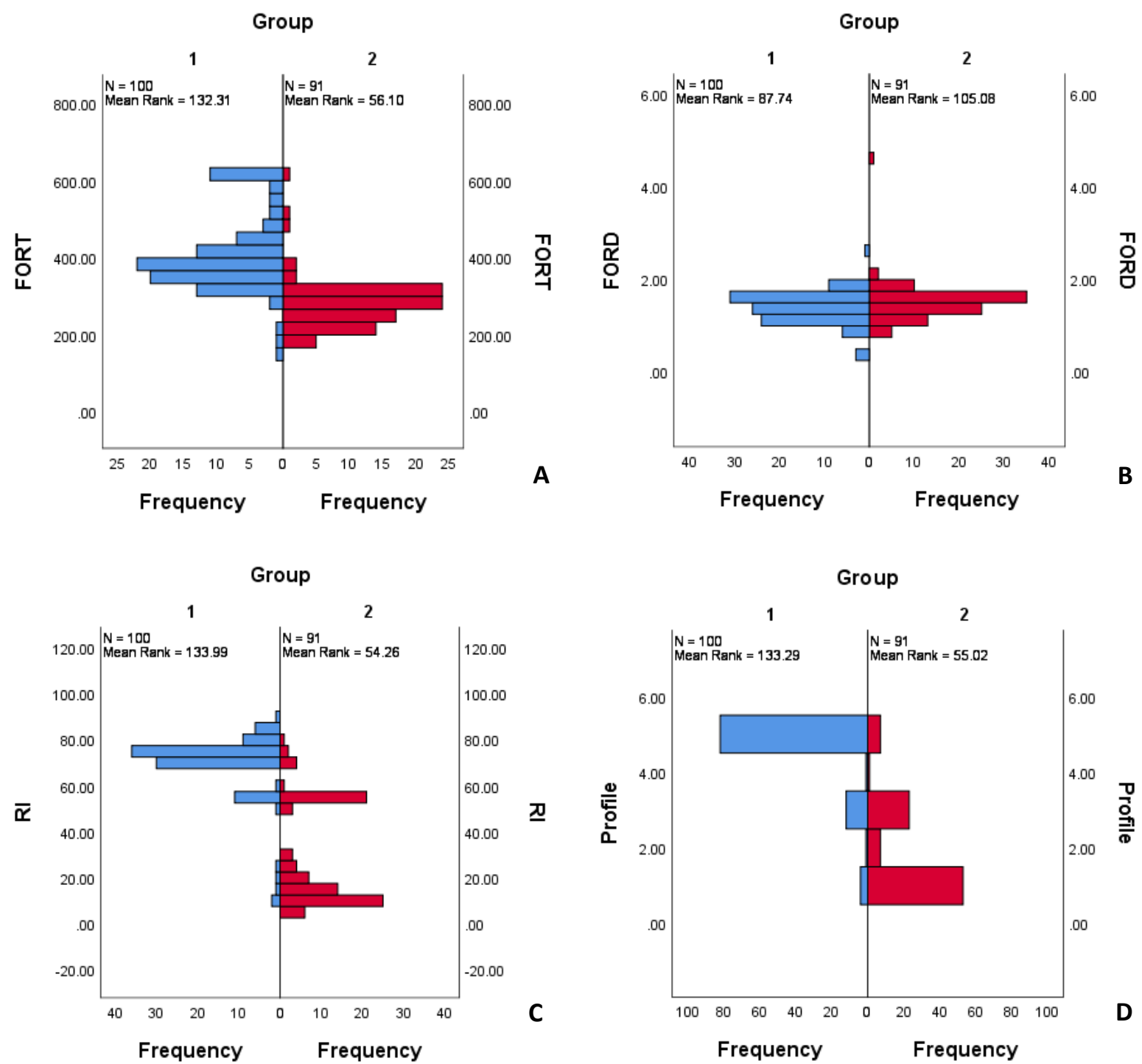

Fig. 1. Distribution of baseline oxidative stress parameters across the groups by the Independent-Samples Mann-Whitney U test.

Notes. Group 1, the patients with acute coronary syndrome (ASC). Group 2, the patients with chronic coronary syndrome (CCS). (A) Distribution of FORT, free oxygen radical test results across the groups (Mann-Whitney U=919, Wilcoxon W=5105, Test statistic=919, Standard error=381.448, Standardized test statistic=-9.519, Asymptotic Sig. (2-sided test) =.000); (B) Distribution of FORD, free oxygen radicals defense test result across the groups (Mann-Whitney $U=5376$, Wilcoxon W=9562, Test statistic $=5376$, Standard error $=381.480$, Standardized test statistic $=2.165$, Asymptotic Sig. (2-sided test) $=.030) ;(C)$ Distribution of calculated RI, REDOX index across the groups (Mann-Whitney $U=751.5$, Wilcoxon $W=4937.5$, Test statistic $=751.5$, Standard error $=381.173$, Standardized test statistic $=-9.965$, Asymptotic Sig. (2-sided test) $=.000) ;(D)$ Profile distribution across the groups (Mann-Whitney $U=821$, Wilcoxon $W=5007$, Test statistic $=821$, Standard error=355.1, Standardized test statistic $=-10.501$, Asymptotic Sig. (2-sided test) $=.000)$.

The evaluation results of association between an exposure (oxidative stress) and an outcome (acute coronary syndrome) are shown in Table 2.

Fig. 3 depicts the stratification of patients in the two groups in line with systemic oxidative stress profile.

A cross-tabulation analysis was performed to assess the sensitivity and specificity, positive and negative predictive values (PPV and NPV, respectively), and positive and negative like- lihood ratios (LR+ and LR-, respectively) for systemic oxidative stress in the patients with acute coronary syndrome (Fig. 4). An informedness of sensitivity and specificity data was represented by positive Youden's index (J). There were following diagnostic characteristics of systemic oxidative stress for ACS: sensitivity of $82 \%$, and specificity of $92.3 \%$; positive predictive value (PPV) of $92 \%$ versus negative predictive value (NPV) of 82\%; positive likelihood ratio (LR+) of 11 versus negative likelihood ratio (LR-) of 0.2. 

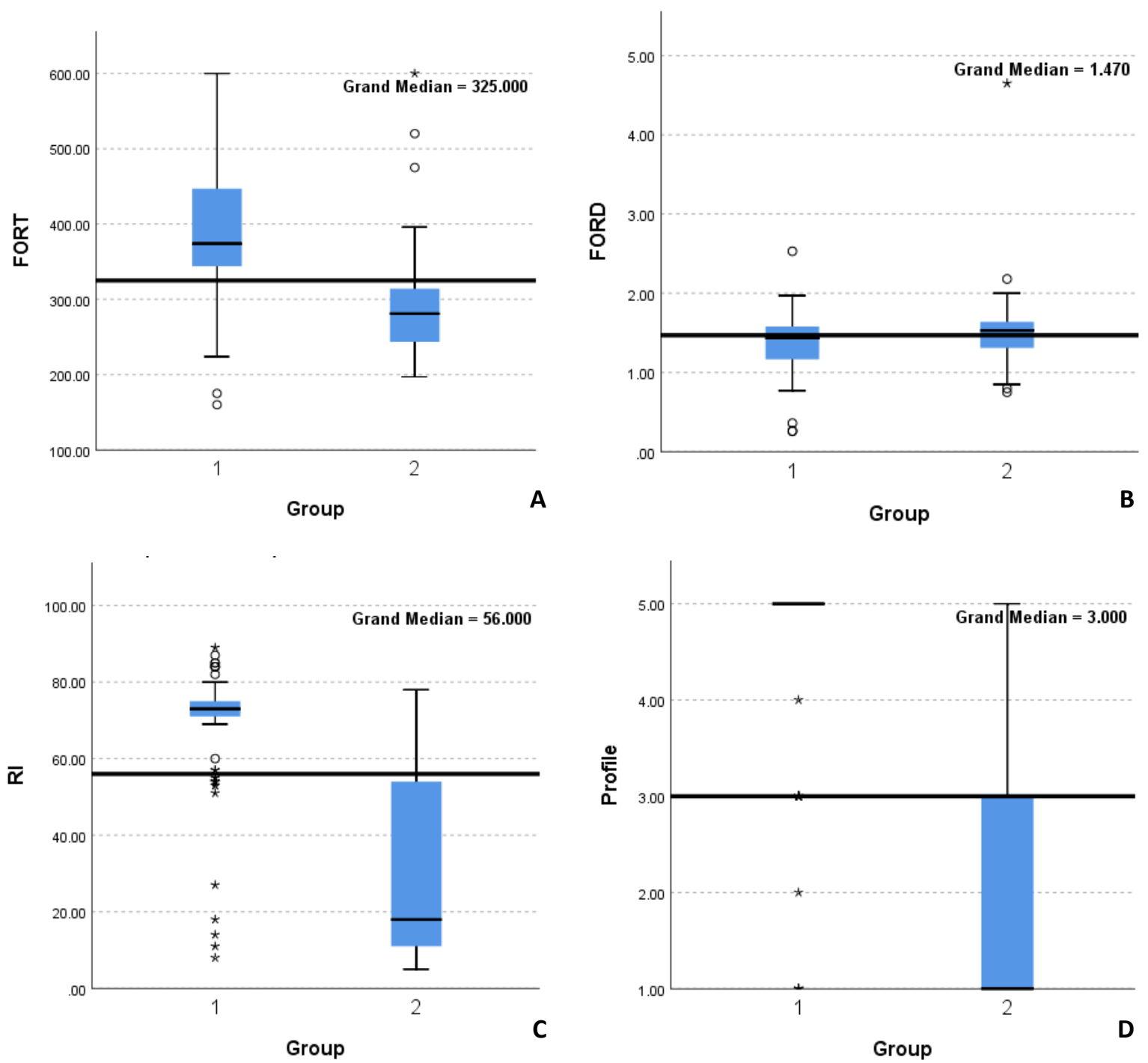

Fig. 2. Independent-Samples Median Test of baseline oxidative stress parameters across the groups. Notes. Group 1, patients with acute coronary syndrome (ASC). Group 2, patients with chronic coronary syndrome (CCS). (A) FORT, free oxygen radical test results across the groups (Median $=325$, Test statistic $=99.317$, Degree of freedom $=1$, Asymptotic Sig. (2-sided test) =.000; Yates's Continuity correction Chi-Square=96.447, Degree of freedom=1, Asymptotic Sig. (2-sided test) =.000); (B) FORD, free oxygen radicals defense test result across the groups (Median=1.470, Test statistic $=3.198$, Degree of freedom=1, Asymptotic Sig. (2-sided test) $=.074$; Yates's Continuity correction Chi-Square $=2.7$, Degree of freedom $=1$, Asymptotic Sig. (2-sided test) =.1); (C) RI, REDOX index across the groups (Median=56, Test statistic=104.393, Degree of freedom=1, Asymptotic Sig. (2-sided test) =.000; Yates's Continuity correction Chi-Square $=101.454$, Degree of freedom=1, Asymptotic Sig. (2-sided test) =.000); (D) Profile across the groups (Median=3.0, Test statistic=105.183, Degree of freedom=1, Asymptotic Sig. (2-sided test) $=.000$; Yates's Continuity correction Chi-Square=102.229, Degree of freedom=1, Asymptotic Sig. (2-sided test) $=.000$ ).

Table 2. The strength of association between oxidative stress and acute coronary syndrome

\begin{tabular}{|l|c|c|}
\hline \multirow{2}{*}{} & Odds ratio (OR) & Relative risk (RR) \\
\cline { 2 - 3 } & 14.42 & 3.26 \\
\hline Standard Error (SR) & 0.36 & 0.18 \\
\hline Lower 95\% confidence Interval (CI) & 7.08 & 2.31 \\
\hline Upper 95\% confidence Interval (CI) & 29.4 & 4.60 \\
\hline
\end{tabular}

Discussion

Oxidative stress is one of the key pathogenetic factors for various diseases, including life-threatening conditions, such as acute coronary syndrome (ACS) [16] mainly caused by atherosclerotic plaque instability $[14,15]$.

Available scientific data extend our understanding of the biology of plaque vulnerability 

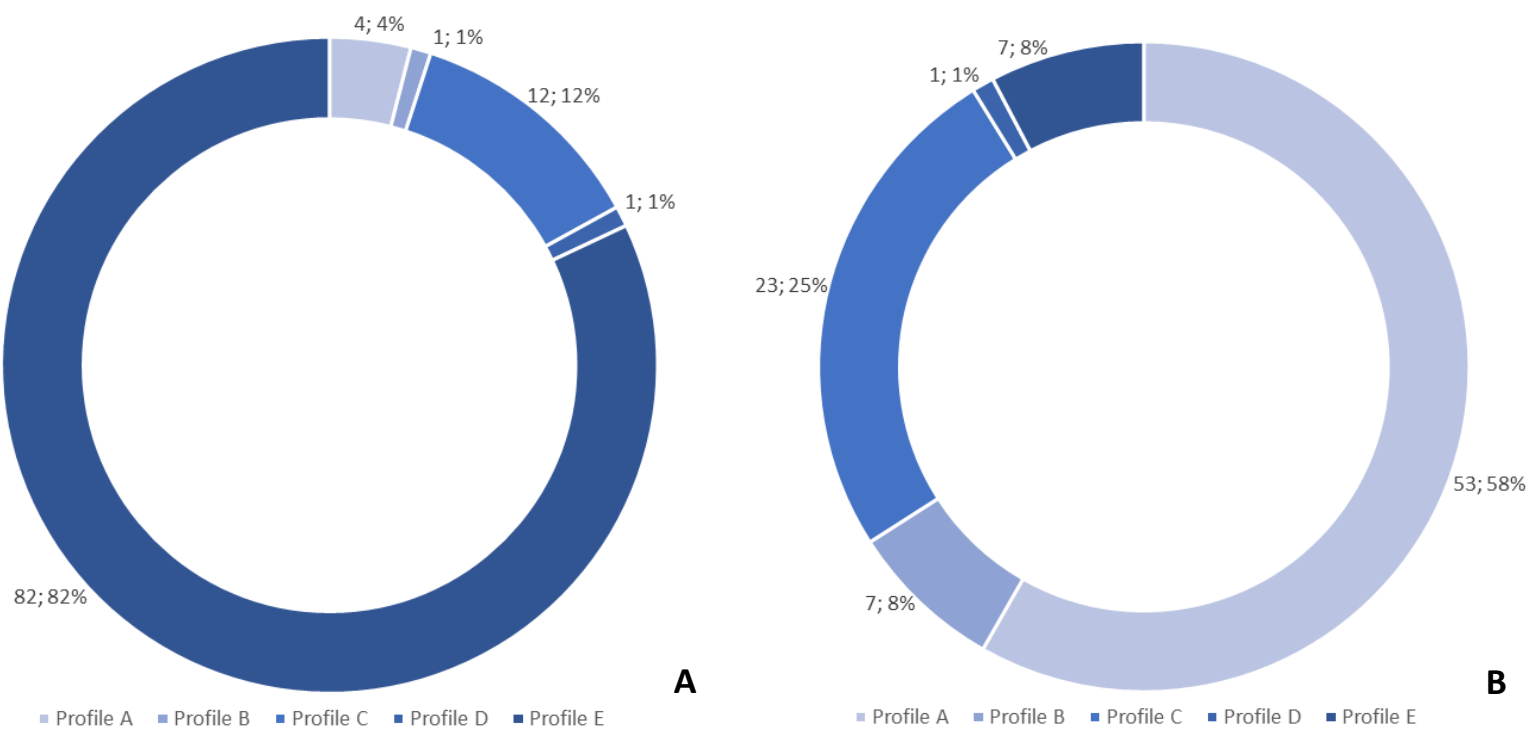

Fig. 3. Doughnut chart of systemic oxidative stress profile frequency in the two groups.

Notes. A. Group 1, patients with acute coronary syndrome (ACS);

$B$. Group 2, patients with chronic coronary syndrome (CCS);

Profile A, (Ideal/normal values): redox index: 0-25; FORT <300 units/2.36 mmol/l $\mathrm{H}_{2} \mathrm{O}_{2}$ eq; FORD $\geq 1.08 \mathrm{mmol} / \mathrm{l}$ trolox eq. Profile $B$, (latent oxidative stress): redox index: 25-50; FORT <300 units $/ 2.36 \mathrm{mmol} / \mathrm{l} \mathrm{H}_{2} \mathrm{O}_{2}$ eq; FORD $\leq 1.07 \mathrm{mmol} / \mathrm{l}$ trolox eq.

Profile C, (compensated oxidative stress): redox index: 50-58.3; $300<$ FORT $<330$ units $/ 2.36 \mathrm{mmol} / \mathrm{I} \mathrm{H}_{2} \mathrm{O}_{2}$ eq; FORD $\geq 1.08 \mathrm{mmol} / \mathrm{I}$ trolox eq. Profile $D$, (at risk of oxidative stress): redox index: 58.3-66.6; $300<F O R T<330$ units/2.36 mmol/I $\mathrm{H}_{2} \mathrm{O}_{2}$ eq; FORD $\leq 1.07$

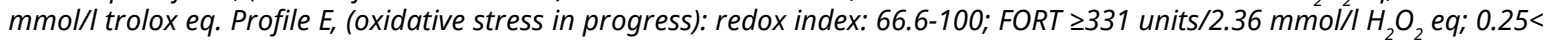
FORD $<3.00 \mathrm{mmol} / \mathrm{l}$ trolox eq. $p$ value $<.0001$.

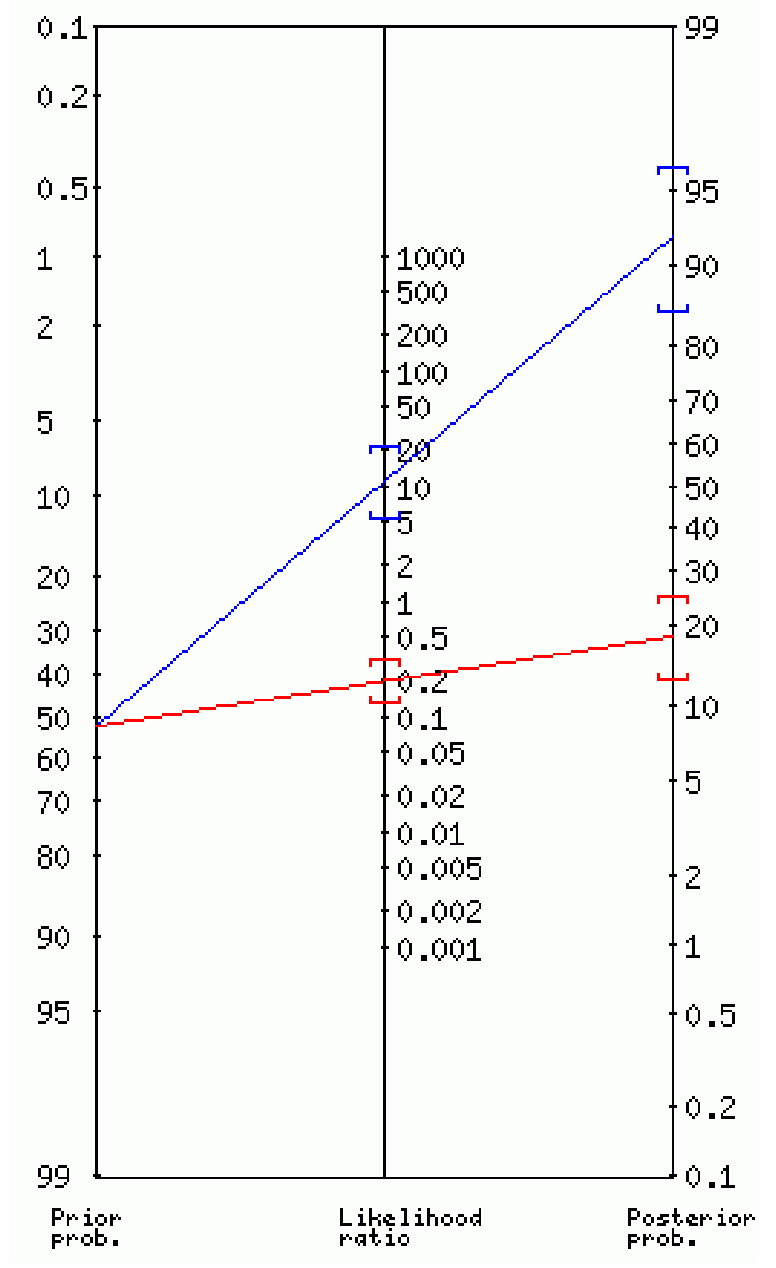

and suggest the important role of ROS as a plaque stability regulator and mediator of acute coronary events [17]. It appears that ROS production might be considered as a marker of atherosclerotic plaque instability.

The main goal of the present study was to compare the oxidative stress profile between two groups of patients with acute coronary syndrome (ACS) and chronic coronary syndrome (CCS). These findings could help assess risk of stratification and prevent acute coronary syndrome (ACS).

Recent studies have shown the usefulness of the free oxygen radical test (FORT)/free oxygen radicals defense (FORD) novel colorimetric assay for evaluating oxidative stress [18-22].

Fig. 4. The likelihood ratio (LR) nomograms of combination of laboratory and clinical findings in patients with Acute Coronary Syndrome (ACS)

Prior probability (odds): $52 \%$ (1.1). Positive test: positive likelihood ratio $11,95 \%$ confidence interval [5.20,22]; Posterior probability (odds) 92\% (12.1), 95\% confidence interval: [85\%,96\%]; $(\sim 1$ in 1.1 with positive test are sick). Negative test: Negative likelihood ratio $0.20,95 \%$ confidence interval $[0.13,0.30]$; Posterior probability (odds): $18 \%$ (0.2), 95\% confidence interval $[12 \%, 25 \%](\sim 1$ in 1.2 with negative test are well). 
Using the CR3000 FORM PLUS (CallegariSrl, Catellani Group, Italy) - Callegari Point of Care instrument we have assessed oxidative stress profile in 191 patients divided into Group 1 and Group 2 with 100 patients with acute coronary syndrome (ACS), and 91 patients with chronic coronary syndrome (CCS), respectively. The characteristics of the study population were well matched between groups (Table 1), except nitrates consumption - it was much higher in the Group 2 in a cohort of patients with chronic coronary syndrome $(p<0.0001)$.

The blood concentration of free oxygen radicals (FORT) at admission in the coronary care unit (CCU) of LTD Clinic-LJ (Kutaisi, Georgia) was much higher in the patients with acute coronary syndrome in comparison of the patients with chronic coronary syndrome: 404.37 \pm 9.83 Fort units $/ 2.36 \mathrm{mmol} / \mathrm{l} \mathrm{H2O}$ eq, and $282.34 \pm 9.83$ Fort units $/ 2.36 \mathrm{mmol} / \mathrm{l} \mathrm{H} 2 \mathrm{O} 2$ eq., respectively $(p<0.0001)$.

The analysis of an antioxidant defense potential (measured by the FORD test) across the groups have shown higher concentration of free oxygen radicals in cases of acute coronary syndrome (mean value of FORD $1.37 \pm 0.035 \mathrm{mmol} / \mathrm{l}$ Trolox eq. for ACS versus $1.5 \pm 0.045 \mathrm{mmol} / \mathrm{I}$ Trolox eq. for CCS).

The calculated REDOX index in the patients with ACS (Group 1) was significantly higher than in the patients with CCS $(69.2 \pm 1.47$ vs $1.5 \pm 0.45$, $p<0.0001$ ).

The analysis of overall oxidative status (derived from FORT/FORD values and calculated REDOX index) across groups has indicated to significant correlation of uncontrolled systemic oxidative stress (Profile $\mathrm{E}$, oxidative stress in progress) with acute coronary syndrome (4.56 \pm 0.1 for Group 1 vs $1.92 \pm 0.13$ for Group 2, $p<0.0001$ ). The incidence of Profile $E$ (oxidative stress in progress) in the patients with acute coronary syndrome was $82 / 100$ (82\%) versus $7 / 91(8 \%)$ in the patients with chronic coronary syndrome.

A cross-tabulation analysis has shown high diagnostic characteristics of systemic oxidative stress measurement test in cases of acute coronary syndrome (sensitivity of $82 \%$, and specificity of 92.3\%; positive predictive value (PPV); positive likelihood ratio (LR+) of 11).

Finally, we have recognized three main limitations to the presents study. First, this was case-control design study. Second, this was not a multi-center study. Third, the sample size was small. Therefore, we are not able to extrapolate the findings of the present study to the general population.

\section{Conclusions}

An extremely strong association between absolute oxidative stress and Acute Coronary Syndrome (OR 14.42 95\% CI (7.08-29.4), RR 3.26 $95 \% \mathrm{CI}(2.31-4.60)$, high sensitivity and specificity ( $82 \%$ and $92.3 \%$, respectively), and strong positive prediction and likelihood (positive predictive value of $92 \%$ and positive likelihood ratio of 11) indicate to pivotal role of oxidative stress in the development of life-threatening acute coronary events. It seems to be a reliable surrogate of plaque instability and rupture predictor.

The findings of our study could help in risk stratification and prevention of acute coronary syndrome (ACS) in clinical setting.

\section{Conflict of Interests}

The authors declare no conflict of interest. Author Contributions

Zaza Lominadze - data curation, formal analysis, funding acquisition, investigation, resources and writing original draft; Kakhaber Chelidze - conceptualization, formal analysis, methodology, project administration, supervision, validation and review and editing of original draft; Levan Chelidze - formal analysis, software, visualization and review and editing of original draft; Ekaterine Lominadze - formal analysis, visualization and review and editing of original draft.

\section{Funding}

The study was supported by LTD Clinic-LJ (Kutaisi, Georgia) funding. 


\title{
ОКСИДАТИВНИЙ СТРЕС - ЯК СУРОГАТ НЕСТАБІЛЬНОСТІ КОРОНАРНОЇ АТЕРОСКЛЕРОТИЧНОЇ БЛЯШКИ ТА ПРЕДИКТОР ІІЇ РОЗРИВУ
}

\author{
Z. Lominadze', K. Chelidze ${ }^{2 *}$, L. Chelidze' ${ }^{2}$ E. Lominadze ${ }^{2}$ \\ 1 - LTD CLINIC-LJ, KUTAISI, GEORGIA \\ 2 - TBILISI STATE MEDICAL UNIVERSITY, TBILISI, GEORGIA
}

Вступ. Оксидативний стрес відіграє важливу роль у патогенезі багатьох захворювань, в тому числі атеросклерозу та його ускладнень, як гострий коронарний синдром (ГКС), що переважно зумовлений нестабільністю атеросклеротичної бляшки.

Мета - з'ясувати взаємозв'язок ступенем оксидативного стресу та нестабільністю бляшки шляхом порівняння оксидативного профілю пацієнтів з ГКС та хронічним коронарним синдромом (ХКС). Дослідження проводили у кардіологічному відділені LTD Клініки-LJ (Кутаїсі, Грузія) в період з квітня 2018 року до червня 2019 року серед пацієнтів, котрим успішно було проведено первинні перкутанні коронарні втручання (ПКВ).

Методи. До дослідження було залучено 191 пацієнта (100 пацієнтів з ГКС (Група 1) ma 91 nayiєнm з ХКС (Група 2). Досліджували такі показники: тест для визначення інтенсивності вільнорадикальних реакцій (Free Oxygen Radical Test, FORT); тест для визначення антиоксидантної здатності (Free Oxygen Radicals Defense Test, FORD); визначали REDOX індекс та Профіль оксидативного стресу за допомогою CR3000 FORM PLUS (Callegari Srl, Catellani Group, Italy).

Результати. Концентрація вільних радикалів кисню була достовірно вищою у пацієнтів з ГКС

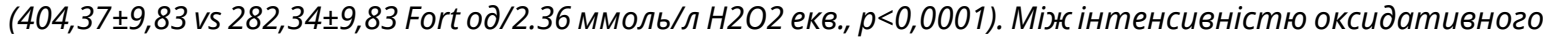
стресу та розвитком гострого коронарного синдрому встановлено вірогідні кореляційні зв'язки (OR 14,42 95\% CI (7.08-29.4), RR 3,26 95\% CI (2,31-4,60) з високими діагностичними характеристиками (чутливість 82,0\% та специфічність 92,3\%; позитивна прогностична роль 92,0\% та позитивний коефіцієнт вірогідності 11).

Висновки. Оксидативний стрес відіграє вирішальну роль при гострих коронарних подіях, що загрожують життю. Вимірювання оксидативного профілю, як сурогату нестабільності атеросклеротичної бляшки та предиктора ії розриву, може допомогти лікарю у стратифікації ризику коронарних подій для попередження гострого коронарного синдрому (ГКС).

КЛЮЧОВІ СЛОВА: Гострий коронарний синдром; хронічний коронарний синдром; оксидативний стрес; тест для визначення інтенсивності вільнорадикальних реакцій (Free Oxygen Radical Test, FORT); тест для визначення антиоксидантної здатності (Free Oxygen Radicals Defense Test, FORD); REDOX індекс; профіль оксидативного стресу; нестабільна бляшка; розрив бляшки.

Information about authors

Zaza Lominadze - MD. LTD Clinic-LJ. Director. Kutaisi, Georgia

ORCID: https://orcid.org/0000-0003-3537-1365, e-mail: lozano_vaneli@yahoo.com

Kakhaber Chelidze - MD, Ph.D., Professor, Tbilisi State Medical University (TSMU). The TSMU First University Clinic. Department of Internal Medicine. Tbilisi, Georgia.

ORCID: https://orcid.org/0000-0002-3906-9967, e-mail: k.chelidze@tsmu.edu

Levan Chelidze - MD. Tbilisi State Medical University (TSMU). Department of Internal medicine. Tbilisi, Georgia.

ORCID: https://orcid.org/0000-0003-4200-300X, e-mail: levachello@gmail.com

Ekaterine Lominadze - MD. Tbilisi State Medical University (TSMU). Department of Internal medicine. Tbilisi, Georgia.

ORCID: https://orcid.org/0000-0002-6152-2852, e-mail: eka@lominadze.ge

\section{References}

1. Global Health Observatory (GHO) data. World Health Organization 2018. https://www.who.int/ gho/mortality_burden_disease/causes_death/ top_10/en/.

2. Zègre-Hemsey JK, Asafu-Adjei J, Fernandez A, Brice J. Characteristics of prehospital electrocardiogram use in north carolina using a novel linkage of emergency medical services and emergency depart- ment data. Prehospital Emergency Care. 2019 Nov 2;23(6):772-9.

doi: 10.1080/10903127.2019.1597230

3. Finn AV, Nakano M, Narula J, Kolodgie FD, Virmani R. Concept of vulnerable/unstable plaque. Arteriosclerosis, thrombosis, and vascular biology. 2010 Jul 1;30(7):1282-92.

doi: 10.1161/ATVBAHA.108.179739 
4. Lafont A. Basic aspects of plaque vulnerability. Heart. 2003 Oct 1;89(10):1262-7.

doi: $10.1136 /$ heart.89.10.1262

5. Davies MJ, Thomas A. Thrombosis and acute coronary-artery lesions in sudden cardiac ischemic death. New England Journal of Medicine. 1984 May 3;310(18):1137-40.

doi: 10.1056/nejm198405033101801

6. Virmani R, Kolodgie FD, Burke AP, Farb A, Schwartz SM. Lessons from sudden coronary death: a comprehensive morphological classification scheme for atherosclerotic lesions. Arteriosclerosis, thrombosis, and vascular biology. 2000 May;20(5):1262-75. doi: 10.1161/01.atv.20.5.1262

7. Mughal MM, Khan MK, DeMarco JK, Majid A, Shamoun F, Abela GS. Symptomatic and asymptomatic carotid artery plaque. Expert Rev Cardiovasc Ther. 2011; 9:1315-30.

doi: $10.1586 /$ erc. 11.120

8. Redgrave JN, Gallagher P, Lovett JK, Rothwell PM. Critical cap thickness and rupture in symptomatic carotid plaques: the oxford plaque study. Stroke. 2008; 39:1722-9.

doi: $10.1161 /$ strokeaha.107.507988

9. Pelisek J, Eckstein H-H, Zernecke A. Pathophysiological mechanisms of carotid plaque vulnerability: impact on ischemic stroke. Arch Immunol Ther Exp (Warsz). 2012; 60:431-42.

doi: $10.1007 / \mathrm{s} 00005-012-0192-z$

10. Saba L, Potters F, van der Lugt A, Mallarini G. Imaging of the fbrous cap in atherosclerotic carotid plaque. Cardiovasc Intervent Radiol. 2010; 33:681-9. doi: 10.1007/s00270-010-9828-8

11. Marnane M, Prendeville S, McDonnell C, Noone I, Barry M, Crowe M, et al. Plaque infammation and unstable morphology are associated with early stroke recurrence in symptomatic carotid stenosis. Stroke. 2014; 45:801-6.

doi: $10.1161 /$ strokeaha.113.003657

12. Madamanchi NR, Hakim ZS, Runge MS. Oxidative stress in atherogenesis and arterial thrombosis: the disconnect between cellular studies and clinical outcomes. Journal of Thrombosis and Haemostasis. 2005 Feb;3(2):254-67.

doi: 10.1111/j.1538-7836.2004.01085.x

13. Mury P, Chirico EN, Mura M, Millon A, CanetSoulas E, Pialoux V. Oxidative Stress and Inflammation,
Key Targets of Atherosclerotic Plaque Progression and Vulnerability: Potential Impact of Physical Activity. Sports Med. 2018;48(12):2725-41.

doi: $10.1007 / \mathrm{s} 40279-018-0996-z$

14. Shao B and Heinecke JW: HDL, lipid peroxidation, and atherosclerosis. J Lipid Res 50:599601, 2009.

doi: 10.1194/jlr.e900001-jlr200

15. Valko M, Rhodes C, Moncol J, Izakovic MM, Mazur M. Free radicals, metals and antioxidants in oxidative stress-induced cancer. Chemico-biological interactions. 2006 Mar 10;160(1):1-40.

doi: 10.1016/j.cbi.2005.12.009

16. Bastani A, Rajabi S, Daliran A, Saadat H, Karimi-Busheri F. Oxidant and antioxidant status in coronary artery disease. Biomedical reports. 2018 Oct 1;9(4):327-32.

doi: $10.3892 /$ br.2018.1130

17. Channon KM. Oxidative stress and coronary plaque stability. Arterioscler Thromb Vasc Biol. 2002;22(11):1751-2.

doi: 10.1161/01.atv.0000042203.08210.17

18. Pavlatou MG, Papastamataki M, Apostolakou F, Papassotiriou I, Tentolouris N. FORT and FORD: Two Simple and Rapid Assays in the Evaluation of Oxidative Stress in Patients with Type 2 Diabetes Mellitus. Metabolism 2009 Nov;58(11):1657-62.

19. Garelnabi MO, Brown WV, Le NA. Evaluation of a novel colorimetric assay for free oxygen radicals as marker of oxidative stress. Clinical biochemistry. 2008 Oct 1;41(14-15):1250-4.

doi: 10.1016/j.clinbiochem.2008.07.009

20. Lorgis I, Zeller M, Dentan G, Sicard P, Richard C, Buffet P, L'Huillier I, Beer J C, Cottin Y, Rochette R, Vergely C. The Free Oxygen Radicals Test (FORT) to Assess Circulating Oxidative Stress in Patients with Acute Myocardial Infarction. Atherosclerosis. 2010 Dec;213(2):616-21.

21. Park S-Y, Lee S-P. The Relationship between Oxidative Stress and Oxidative Markers. Korean J Clin Lab Sci 2014,46:31-7.

22. Lewis NA, Newell J, Burden R, Howatson G, Pedlar CR. Critical Difference and Biological Variation in Biomarkers of Oxidative Stress and Nutritional Status in Athletes. PLoS One. 2016;11(3):e0149927. doi: $10.1371 /$ journal.pone.0149927

Received 30 Mar 2020; revised 13 Apr 2020; accepted 02 June 2020.

This is open access article distributed under the Creative Commons Attribution License, which permits unrestricted use, distribution, and reproduction in any medium, provided the original work is properly cited. 